\title{
THE IMPLEMENTATION OF CORPORATE SOCIAL RESPONSIBILITY AS A LEGAL OBLIGATION FOR PLANTATION COMPANIES IN SELUMA REGENCY
}

By :

M. Alvin Azhari, Widiya N. Rosari, Candra Irawan

\begin{abstract}
This study aimed to examine and analyze the implementation of corporate social responsibility as a legal obligation for plantation companies in Seluma Regency carried out by PTPN VII of Padang Pelawi Business Unit. The type of this study was juridical empirical with descriptive research design. The results of this study indicated that the implementation of CSR by PTPN VII of Padang Pelawi Business Unit had been carried out with the Partnership and Community Development Program (known as $P K B L$ in Indonesian abbreviation) based on the State-Owned Enterprise Ministerial Regulation Number: 09/MBU/07/2015 concerning the Partnership and Community Development Program for State-Owned Enterprises and its amended regulations. However, it had not been running optimally. Matters that need to be revised and improved besides continuing to implement the $P K B L$ program that have been carried out were continue to enhance other CSR activities, especially those related to efforts to improve community welfare by increasing business capital assistance in the Partnership Program, and to provide access to information as well as to establish communication with the community so that CSR objectives can be more optimal.
\end{abstract}

Keywords: Implementation, CSR, Legal Obligation, PTPN VII of Padang Pelawi Business Unit, Seluma Regency. 


\section{A. INTRODUCTION}

\section{Research Background}

The provision of Article 33 paragraph (4) of the 1945 Constitution states that the national economy is organized based on economic democracy with the principles of togetherness, efficiency, justice, sustainability, environmental awareness, independence, and maintaining a balance between progress and national economic unity. The development of the national economy which is carried out on the basis of these principles aims to create public welfare. The welfare of the Indonesian people is the responsibility of all stakeholders such as the state and business actors who luxuriate the wealth of the Republic of Indonesia. One form of the responsibility of business actors to society is social responsibility known as Corporate Social Responsibility (CSR). ${ }^{1}$

$$
\text { Corporate }
$$

Social

Responsibility or commonly abbreviated as CSR is the commitment of companies or the business world to contribute to

1 Umar Hasan, Kewajiban Corporate Social Responsibility (CSR) Dilihat dari Perspektif Hukum, Forum Akademika Legal Magazine, Number 1 of 2014, pp 1-2. sustainable economic development by paying attention to corporate social responsibility and by emphasizing the balance between attention to economic, social and environmental aspects. $^{2}$

According to Candra Irawan, CSR is actually more ethical (moral / ethical). Based on ethics/morals, a business actor or business entity that does not want to do well to others and the environment can be as bad (immoral) business actor, because ethical principle is an assessment of good and bad. In general, CSR is a comprehensive contribution from business actors to sustainable development by considering the economic, social and environmental impacts of their business activities. ${ }^{3}$

The main business of a company is a production activity that produces products in the form of goods and an offering activity in the form of service products to generate maximum profit. But on the other hand, the company's activities, especially in the industrial sector, have caused problems in the environment and the economic level

\footnotetext{
${ }^{2}$ Hendrik Budi Untung, Corporate Social Responsibility, Sinar Grafika, Jakarta, 2008, p.1.

${ }^{3}$ Candra Irawan, Dasar-Dasar Pemikiran Hukum Ekonomi Indonesia, Mandar Maju, Bandung, 2016, p. 25.
} 
of the people in a region. This situation is worsen by the company's inadequate response to various demands of the community regarding environmental, welfare, and other issues by the company. Busyra Azheri argues, this is due to the company's culture which is dominated by a way of thinking and economic behavior which is only profit oriented. ${ }^{4}$

In the provision of Article 1 point 3 of Law no. 40 of 2007 regarding Limited Liability Companies, CSR is defined as social and environmental responsibility, which is the Company's commitment to participate in sustainable economic development in order to improve the quality of life and the environment that is beneficial, both for the Company itself, the local community, and society in general. Moreover, in Article 74 of Law no. 40 of 2007 concerning Limited Liability Companies states that companies that carry out their business activities in the field and/or related to natural resources are required to carry out social and environmental responsibility. Social

4 Busyra Azheri, Corporate Social Responsibility: Dari Voluntary Menjadi Mandatory, Rajawali Pers, Jakarta, 2012, p.3. and Environmental Responsibility is the obligation of the Company which is budgeted and calculated as the cost of the Company whose implementation is carried out with due regard to appropriateness and fairness. Meanwhile, in the provision of Article 15 letter b of Law no. 25 of 2007 concerning Investment confirms that every investor is obliged to carry out corporate social responsibility.

CSR in Indonesia is normatively required under the law, so that CSR has two responsibilities at once, namely the responsibility to obey the law (legal responsibility) and social and environmental responsibility. $^{5}$

Plantation Company is one type of company which done business activities by managing and utilizing natural resources. In Seluma Regency, the plantation sector is one of the drivers of the regional economy because it has a very wide multiplier effect, such as growing related service industries, providing business fields, and absorbing labor. With the potential of this plantation, it is fitting for plantation companies investing in

\footnotetext{
${ }^{5}$ Candra Irawan, Loc Cit, p.25.
} 
Seluma Regency to have more social responsibility by implementing CSR in a sustainable manner.

Departing from these problems, CSR activities are an ongoing commitment from the company to be jointly responsible for social problems, not just activities that focus on generosity (philanthropy) and generosity (charity) but have become a legal obligation (legal mandatory) of the company.

From the description above, the writer was interested in conducting a study and compiling it in a journal entitled Implementation of Corporate Social Responsibility as a Legal Obligation in Plantation Companies in Seluma Regency.

\section{Identification of problems}

How was the Implementation of Corporate Social Responsibility as a Legal Obligation by PTPN VII of Padang Pelawi Business Unit?

\section{B. RESEARCH METHODS}

This study was a legal research with juridical empirical design. This study will describe the implementation of corporate social responsibility as a legal obligation for plantation companies in Seluma Regency carried out by PTPN VII of Padang Pelawi Business Unit. The primary data collection conducted by researchers in the field was obtained from the results of interviews. The secondary data were gotten from library sources in the form of laws and regulations, books, journals, and articles both online and offline media related to CSR by using library study techniques. Then the data were processed and analyzed by using qualitative analysis methods.

\section{RESEARCH RESULTS AND DISCUSSION}

Implementation of Corporate Social Responsibility as a Legal Obligation by PTPN VII of Padang Pelawi Business Unit

In this research, the research location is PTPN VII of Padang Pelawi Seluma Business Unit which was a state-owned plantation company located in the Seluma Regency area of Bengkulu Province. To implement CSR, the companies are required to compile, organize, design and implement CSR activities in accordance with the principles of social responsibility in the business world with due observance to applicable laws and regulations, which were stipulated through regulations such as laws, government regulations, ministerial regulations, to regulations regions, or regulations 
made based on agreements between companies and institutions.

The implementation of CSR by PTPN VII of Padang Pelawi Business Unit is known as PKBL, namely the Partnership Program and the Community Development Program. The BUMN companies are more familiar with the term CSR with PKBL (Partnership and Community Development Program), because in law the government uses the term PKBL for BUMN. ${ }^{6}$

According to Achmad Rizal, the $P K B L$ program is one part of corporate social responsibility or CSR. While the technical implementation of $P K B L$ is based on the Regulation of the Minister of BUMN Number: Per09/MBU/07/2015 concerning Partnership and Environmental Development Programs for StateOwned Enterprises, along with the amendements to the Regulation of the Minister of BUMN Number: PER03/MBU/12/2016, and Regulation of the Minister of BUMN Number: PER-02/MBU/7/2017.

As for the source of the PKBL funds Program of PTPN VII of

6 Achmad Rizal, Assistant General Manager and HR of PTPN VII of Padang Pelawi Business Unit, interviewed on $11^{\text {th }}$ of June 2010 at $09.30 \mathrm{pm}$.
Padang Pelawi Business Unit comes from direct costs of the company's operational activities, from the company's profit allowance, which was allocated for the Partnership and Community Development Program of $3 \%$ (three percent), revolving funds for loan repayments from fostered partners are given back as loans to the community in the form of a Partnership Program / additional business capital.

\section{1) Partnership Program.}

The Partnership Program is a program to improve the ability of small businesses to become resilient and independent. As stated by Achmad Rizal, the partnership program is to provide loan capital to people who want to open a business or develop their business; this assistance is only given to micro, small and medium enterprises (MSMEs).

Then regarding the procedures for distributing partnership program loan fund as follows:

1. The prospective Foster Partners submit a letter of request for assistance with a business proposal attached to the PTPN VII of Padang Pelawi 
Business Unit addressed to the Unit Manager.

2. The Work Unit Manager assigns his work unit to $P K B L$.

3. The work unit PKBL evaluates prospective fostered partners in accordance with predetermined provisions.

4. The $P K B L$ work unit conducts a survey of data suitability to the field.

5. The PKNL work unit prepares an official report on the survey results.

6. The Proposals and minutes of work unit $P K B L$ survey results are submitted to the Director of Finance as the $P K B L$ coach at the Office of the Board of Directors of PTPN VII of Bandar Lampung.

7. The $P K B L$ work unit makes a survey result memo to the Finance Director as the supervisor.

8. The Finance Director gives approval / rejection.

Funding assistance begins with submitting proposals from the community to the company, then the proposals received are researched and studied and conducted a survey, whether or not it is useful for this partnership program and for those who were eligible, the company notifies them to prepare files as a condition business capital borrowing. Most of those who received assistance were traders who ran around the location or communities in the buffer villages around the company. ${ }^{7}$

PTPN VII of Padang Pelawi Business Unit also provides guidance to partners, so that the attitudes and behavior of business partners change towards ethical and professional business behavior so that the fostered partners are disciplined in obtaining additional capital. ${ }^{8}$

Development partners who receive loan funds by submitting a guarantee/collateral in the form of a certificate of ownership of motor vehicles $(B P K B)$ to PTPN VII Business Unit of Padang Pelawi. It is known that the development partners are charged an administrative service fee of $3 \%$ (three percent) per year or $0.25 \%$

\footnotetext{
${ }^{7}$ Ibid.

${ }^{8}$ Ibid.
} 
(zero-point twenty-five percent) per month of the initial loan balance. Based on the writer's investigation, the imposition of administrative service fees for development partners is regulated in the provisions of Article 11 paragraph (2) Ministerial Regulation of State-Owned Enterprise Number PER02/MBU/7/2017 that the amount of administrative services for the partnership program loan funds is $3 \%$ (three percent) per year from loan balance at the beginning of the year or otherwise stipulated by the Minister.

Based on the results of the writer's interviews with the development partners regarding the implementation of this $P K B L$ partnership program, the majority said positive things, and they were quite helped in developing their business. They hope that this program can be further developed, especially the value of the loan fund, which is even greater. From the information of the MSMEs as the development partners that the loan funds they receive require a long process and time until the disbursement stage is the fastest when the proposal is approved by the company for about six months.

As for the obligations of the development partners, among others: carry out their business activities in accordance with the designation or according to the plan/proposal which is the basis for providing loans, pay loan installments on time, and convey business developments in accordance with the agreement. ${ }^{9}$

1) Community

Development Program

The Community Development Program is a program to empower community social conditions by $B U M N$. The form of the Community Development Program was implemented by PTPN VII Business Unit of Padang Pelawi, such as providing natural disaster assistance, education, health improvement, developing public infrastructure and/or facilities, worship facilities, nature conservation, community social assistance and so on. ${ }^{10}$

Related to the realization of the form of the community development program by

\footnotetext{
${ }^{9}$ Ibid.

${ }^{10}$ Ibid.
} 
providing assistance for houses of worship, for example, assistance to the Jami 'Nurus Salam mosque which is around the company's location. Then the form of educational assistance such as providing scholarships for employees' children who excel from elementary to high school levels and educational facilities by providing an infocus tool to several schools in the surrounding village environment. The form of health assistance or assistance for the sick, the company has established a Kebun Health Center (Puskesbun) but it is only specifically for company employees or workers, not for the general public. The form of assistance for public facilities and infrastructure means that the company has provided sports field facilities such as soccer fields, multi-purpose buildings, $P A U D / T K, T P Q$, road repairs, repairing broken water culverts around residential areas.

Based on the writer's observations, it is known that the pattern or model in the distribution of the $P K B L$ Program that implemented by PTPN VII Business Unit of Padang Pelawi is a direct involvement pattern, where the company organizes the $P K B L$ program itself, or in other words, the company distributes directly to the community without intermediaries.

The responses related to the operation of PTPN VII Business Unit of Padang Pelawi were given by Johana Satar as the Head of Niur Village that:

"Almost every day in the morning, community members feeling the condition of the environment is quite apprehensive, the air that comes out through the chimney of the rubber processing factory blows in the residential area so that people feel the air they breathe is very bad or unhealthy, very disturbing the respiratory system. ${ }^{11}$

Johana Satar added, even though the community felt the impact, from the PTPN VII Padang Pelawi Business Unit there was no concern to help medical treatment at the hospital if there were local residents due to the impact, they felt from the rubber processing activities the company operated. Not to mention the road damage caused by the

11 Johana Satar, Head of Niur Village, Sukaraja Sub-District, Seluma Regency, interviewed on the $24^{\text {th }}$ of June 2020 at 11.00 WIB. 
burden of transporting rubber trucks passing through the residents' roads and quite disturbing, the hope is that the company will pay attention to the community, especially the people around this company.

Whereas related to rubber processing activities by the company PTPN VII Business Unit of Padang Pelawi which resulted in poor air quality, especially in the morning, the company should provide public health facilities for the community. Road facilities that were damaged as a result of being traversed by rubber transport trucks also caused the roads traversed by residents to be damaged and to be disturbed. It was expected to PTPN VII to pay more attention to the communities around the company's location.

\section{Regarding}

the implementation of the $P K B L$ program, the writer argues that PTPN VII needs communication and accommodates the aspirations of the community in order to create a harmonious relationship with the community and village government, the company needs to collaborate with village government officials and local community leaders so that the goals and objectives of implementing this $P K B L$ program run optimally. But the findings in the field are contradictory, such as the response from Johana Satar, the Head of Niur Village to this partnership program:

"The village government also has questions about the responsibility of the company to the Niur Village Community as the village that supports the company. The Village Government does not know and does not involve in the implementation of CSR or $P K B L$ programs by PTPN VII Business Unit of Padang Pelawi. We only know that there are community members who receive $P K B L$ funds when they process business certificates. "12

From the information that the writer obtains, most of the $P K B L$ fund recipients are those whose families are employees/work at PTPN VII Business Unit of Padang Pelawi. The proposal for the assistance of the community activities in the village often fails to respond from the company with the reason that they must seek approval from the center of the office. 
From the Amri's statement as a community leader, he conveyed the same thing that many people did not know about the CSR or PKBL program implemented by PTPN VII Business Unit of Padang Pelawi, it seemed that the distribution of assistance was not evenly distributed. Regarding the information regarding the PKBL program, the company seems to only inform its employees. ${ }^{13}$

Based on the results and data analysis of research, it is known that PTPN VII Business UnitPadang Pelawi as a stateowned company operating in Seluma Regency has implemented CSR as a legal obligation. This is showed by the implementation of $P K B L$ program fund distribution which is carried out in accordance with the applicable laws and regulations related to the distribution of CSR or PKBL funds based on the Regulation of the Minister of BUMN Number PER-09/MBU/ 07/2015 concerning the Partnership and Community Development

13 Amri, community leader of Niur Village, Sukaraja District, Seluma Regency, interviewed on June 24, 2020, at 16.30 WIB.
Program of State-Owned Enterprises in conjunction with Ministerial Decree of BUMN Number PER-03/MBU/12/2016 in conjunction with Ministerial Regulation of BUMN Number PER-02/MBU/7/2017.

\section{CLOSING}

\section{Conclusion}

CSR implementation carried out by PTPN VII Business UnitPadang Pelawi was the Partnership and Community Development Program (PKBL). On the Partnership Program, it was implemented in the form of providing business capital loan facilities for people who wish to develop their business. While the Community Development Program is carried out in the form of natural disaster relief, education, health improvement, development of public infrastructure and/or facilities, religious facilities, nature preservation, community social assistance, and so on. The implementation of CSR that was conducted by PTPN VII Padang Pelawi Business Unit in accordance with the BUMN Ministerial Regulation Number: 09/MBU/07/2015 concerning the 
Partnership and Community

Development Program for State-

Owned Enterprises and its amended regulations, but has not run optimally due to lack of socialization and communication between the company and the community.

\section{Suggestion}

Matters that need to be improved and enhanced in the implementation of CSR which carried out by PTPN VII Padang Pelawi Business Unit are continue to implement the $P K B L$ program that has been carried out and continue to add other CSR activities, especially those related to efforts to improve community welfare by increasing business capital assistance in Partnership Program and provide access to information and establish communication with the community so that CSR goals can be more optimal.

\section{REFERENCES}

Abdulkadir Muhammad, Hukum Perusahaan Indonesia, PT. Citra Aditya Bakti, Bandung, 2002.

Amirudin dan Zainal Asikin, Pengantar Metode Penelitian Hukum, PT Raja Grafindo Persada, Jakarta, 2013.
Binoto Nadapdap, Hukum Perseroan Terbatas, Permata Aksara, Jakarta, 2012.

Busyra Azheri, Corporate Social Responsibility:Dari Voluntary Menjadi Mandatory, Rajawali Pers, Jakarta, 2012.

Candra Irawan, Dasar-Dasar Pemikiran Hukum Ekonomi Indonesia, Mandar Maju, Bandung, 2016.

Edi Suharto, Pekerjaan Sosial di Dunia Industri, Alfabeta, Bandung, 2009.

Hendrik Budi Untung, Corporate Social Responsbility, Sinar Grafika, Jakarta, 2009.

Umar Hasan, Kewajiban Corporate Social Responsibility (CSR) Dilihat Dari Perspektif Hukum, Majalah Hukum Forum Akademika, Nomor 1 Tahun 2014.

Yusuf Wibisono, Membedah Konsep dan Aplikasi CSR, Fascho Publishing, Gresik, 2007.

Achmad Rizal, Asisten Manajer Umum dan SDM PTPN VII Unit Usaha Padang Pelawi, wawancara tanggal 11 Juni 2010 pukul 09.30 WIB.

Amri, tokoh masyarakat Desa Niur Kecamatan Sukaraja Kabupaten Seluma, wawancara tanggal24 Juni Pukul 14.00 WIB.

Johana Satar, Kepala Desa Niur Kecamatan Sukaraja Kabupaten Seluma, wawancara tanggal 24 Juni 2020 pukul 11.00 WIB.

Siti Syarifah, warga Desa Niur mitra binaan Program Kemitraan PTPN VII Unit Usaha Padang Pelawi, wawancara tanggal 14 Juni 2020 pukul 09.00 WIB

Undang-Undang Nomor 3 Tahun 1982 tentang Wajib Daftar Perusahaan. 
Undang-Undang Nomor 8 Tahun 1997 tentang Dokumen Perusahaan.

Undang-Undang Nomor 19 Tahun 2003 tentang Badan Usaha Milik Negara.

Undang-Undang Nomor 25 Tahun 2007 tentang Penanaman Modal

Undang-Undang Nomor 40 Tahun 2007 tentang Perseroan Terbatas

Peraturan Pemerintah Nomor 47 Tahun 2012 tentang Tanggung Jawab Sosial dan Lingkungan Perusahaan
Peraturan Menteri BUMN Nomor : Per09/MBU/07/2015 tentang Program Kemitraan dan Program Bina Lingkungan Badan Usaha Milik Negara sebagaimana telah diubah beberapa kali terakhir dengan Peraturan Menteri BUMN Nomor : PER-02/MBU/7/2017 tentang Perubahan Kedua Atas Peraturan Menteri BUMN Nomor 09/MBU/07/2015 tentang Program Kemitraan dan Program Bina Lingkungan Badan Usaha Milik Negara 